\title{
THE TEACHERS' ROLES AND STUDENTS' BEHAVIOR IN ENGLISH ONLINE DISTANCE LEARNING
}

\author{
Jayson R. Salvador \\ Master of Arts in Education, Laguna State Polytechnic University, Sta. Cruz, Laguna
}

Article DOI: $\underline{\text { https://doi.org/10.36713/epra7578 }}$

DOI No: 10.36713/epra7578

\begin{abstract}
This study aims to determine the levels of status of the roles of the teachers and behavior of the students in English online distance learning during the first and second grading periods of the school year 2020-2021. There are ninetyfive (95) students who participated in the study. The instrument used to gather data was the questionnaire. Employing the descriptive - survey method of research, the teachers' roles are examined into three categories. These categories are teachers' affective roles, teachers' planner roles, and teachers' managerial roles during the English online distance learning. The roles have 10-item descriptors to describe the online distance learning teachers. The students' behavior is examined into three categories, too. These categories are students' behavior when reading, students' behavior when writing, and students' behavior when viewing and listening during their English online distance learning classes. Each role has 10-item descriptors to describe the behavior of the students. This study hypothesized that there is no significant relationship of the teachers' roles and the students' behavior in English online distance learning during the first and second grading periods of the school year 2020-2021. To test the significant relationship between the teachers' roles and students' behavior, correlation analysis is used.
\end{abstract}

\section{INTRODUCTION}

The Philippines is one of the countries that is greatly affected by the Corona Virus Disease 2019 (COVID19). The schools in the country are now offering online distance learning (ODL) to the students who are willing and capable to access the e-learning platforms so that parents no longer sacrifice their health in procuring printed modules from the school then pass the answer sheets after a week.

In the digital world of continuing the educational process of the learners today, many factors affect their interest in working on their school tasks and assignments at home. One of these factors is the roles of online distance learning teachers. Teachers are playing a significant role in motivating students to attend their classes, either synchronous or asynchronous.

There are roles that a teacher needs to play significantly in online distance learning for the online learners to attend their classes and finish tasks and pass them on time. The first role that a teacher plays is affective roles. Teachers are considered guidance counsellors in this time of the pandemic. The second is the planning or planner roles. The teacher plans and designs his/her classroom based on the lessons and grade level of the students. The last one is the managerial roles. Teachers are considered managers of learning. It is up to the teacher to manage the whole class for the students to learn better.

The students' behavior in attending English online classes is also considered in assessing the significance of online distance learning. Since there is a significant shift in the educational process in the Philippines, students are learning in their own schedule. The learners are working at their own home and on their own time, their behavior in studying English might change from their behavior when they were attending face-to-face classes. 


\section{SJIF Impact Factor 2021: 8.013| ISI I.F.Value:1.241| Journal DOI: 10.36713/epra2016 ISSN: 2455-7838(Online) EPRA International Journal of Research and Development (IJRD) Volume: 6 | Issue: 7 | July 2021 \\ - Peer Reviewed Journal}

Online distance learning is one of the platforms that the department of education chose to offer to continue the education process in the Philippines. In the DepEd order No. 008 series 2020, amid the public health emergency due to COVID-19, DepEd remains committed to finding ways to provide opportunities to all Filipino learners for School Year 2020-2021 through its Basic Education Learning Continuity Plan (BE-LCP). DepEd announced a greater emphasis on multiple learning delivery modalities such as blended learning, distance learning, and homeschooling, on top or to replace face-to-face learning modality to reduce possible exposure of learners and teachers to COVID-19. On the other hand, DepEd order No. 018 series 2020 reiterates that education must be innovative and resourceful in delivering quality, accessible, relevant, and liberating education and ensuring that learning opportunities are safely provided to the learners through different learning delivery.

Online distance learning is a new setup in Philippine education and different teachers' roles and students' behavior are significant factors that contribute to the academic performance of the learners. In English online distance learning, the basic English class skills, reading, writing, listening and viewing, are playing a vital role in understanding English as a whole and the behavior of the students and the roles of the teachers toward these skills affect their level of performance in English subject.

\section{MATERIAL AND METHODS}

The study utilized the descriptive-survey type of research to determine the teachers' roles and students' behavior in English online distance learning students from grades seven to ten during the first grading and second grading periods.

In this study, a descriptive research design describes the gathered data regarding teachers' roles and students' behavior in the English online distance learning during the first and second grading periods of the school year 20202021. It sought to describe how the teachers' roles and the students' behavior can contribute to the academic achievement of the online distance learners in English class.

Purposive sampling technique was used in this study because all the ODL learners were taken as participants. A purposive sample is a non-probability sample that is selected based on the characteristics of a population and the objective of the study. Purposive sampling is also known as judgmental, selective or subjective sampling. This type of sampling can be advantageous in situations when you need to reach a targeted sample quickly and where sampling to proportionality is not the primary concern.

The instrument used to gather data was the questionnaire. Employing the descriptive - survey method of research, the teachers' roles are examined into three categories. These categories are teachers' affective roles, teachers' planner roles, and teachers' managerial roles during the English online distance learning. The roles have 10 -item descriptors to describe the online distance learning teachers.

The students' behaviors are examined into three categories too. These categories are students' behavior when reading, students' behavior when writing, and students' behavior when viewing and listening for their English online distance learning. Each role has 10-item descriptors to describe the behavior of the students.

The Questionnaire was constructed based on the following sections:

Section 1: Characterization of participants in terms of name, grade level, number of hours the students are spending in English online distance learning, types of device that the students are using for the online class, a network used to access the internet, an average time of use of the Internet per day in English class.

Section 2: Characterization of the teachers' roles in being the guidance counsellor, the e-classroom designer, and authority in choosing teaching strategies in English class.

Section 3: Characterization of the students' behavior in terms of reading, writing, listening and viewing the literary materials.

After the questions were constructed and validated, the questionnaire was transformed into google form. The link was sent to the Facebook Messenger of the respondents.

Once the measuring instruments have been retrieved, the researcher processed the raw data into quantitative forms. Data processing involves input. This involves the responses to the measuring apparatus of the subjects of the study.

The frequency distribution was employed in the study to describe variables after the data were coded, tabulated, and analyzed. A frequency distribution is a list, table or graph that displays the frequency of various 


\section{SJIF Impact Factor 2021: 8.013| ISI I.F.Value:1.241| Journal DOI: 10.36713/epra2016 ISSN: 2455-7838(Online) EPRA International Journal of Research and Development (IJRD) Volume: 6 | Issue: 7 | July 2021 \\ - Peer Reviewed Journal}

outcomes in a sample. Each entry in the table contains the frequency or count of the occurrences of values within a particular group or interval, and in this way, the table summarizes the distribution of importance in the sample.

Mean can be considered the center of the gravity of the distribution and is the most appropriate measure of central tendency when the data are in the interval ratio or ratio scale.

Standard Deviation helps to know how a set of data distributes or how to disperse the data are. This calculation is helpful because it allows for the same flexibility regarding further analyses and yet also expresses variation in the same units as the original measurements. To test the significant relationship between the teachers' roles and students' behavior, correlation analysis is used.

\section{RESULTS AND DISCUSSION}

Table 1 presents the level of the teachers' affective roles in English online distance learning. Interesting results were found on the teachers' affective roles in English online distance learning. The roles on listening to the feelings of the students when sharing $(\mathrm{M}=4.07, \mathrm{SD}=1.00)$, helping the students to manage their online schedules $(\mathrm{M}=4.14, \mathrm{SD}=1.00)$, assisting in setting the students' goals and plans every day in taking their online classes $(\mathrm{M}=$ $4.12, \mathrm{SD}=1.07)$, helping the learners in coping with peer relationship in online class $(\mathrm{M}=3.87, \mathrm{SD}=1.14)$, setting challenging educational goals of the learners $(\mathrm{M}=4.16, \mathrm{SD}=0.88)$, helping the learners to establish personal goals $(\mathrm{M}=4.07, \mathrm{SD}=1.01)$, addressing health related problems $(\mathrm{M}=3.49, \mathrm{SD}=1.30)$, and helping the students in dealing with stress and academic difficulty $(\mathrm{M}=3.47, \mathrm{SD}=1.24)$ are all verbally interpreted as Often. This means that the mentioned roles are quite a bit perceived by the learners and they observed these roles often performed by the teachers during the English online distance learning classes.

Table 1. Level of the Teachers' Affective Roles in English Online Distance Learning

\begin{tabular}{|l|l|l|c|}
\hline Statements & Mean & SD & V.I. \\
\hline Listens to your feelings when you are sharing & 4.07 & 1.00 & Often \\
\hline Helps you manage changes in your class schedules & 4.14 & 1.00 & Often \\
\hline Guide you in taking responsibility for your daily activities & 4.31 & 0.95 & Always \\
\hline Assist you in setting your goals and plans every day as you take online classes & 4.12 & 1.07 & Often \\
\hline Help you cope with peer relationship in your online class & 3.87 & 1.14 & Often \\
\hline Set challenging education goals & 4.16 & 0.88 & Often \\
\hline Help you establish personal goals & 4.07 & 1.01 & Often \\
\hline Address health-related problems & 3.49 & 1.30 & Often \\
\hline Help you deal with stress and academic difficulty & 3.47 & 1.24 & Often \\
\hline Coordinate with your parents regarding your academic status in this time of the pandemic & 3.37 & 1.44 & Sometimes \\
\hline Weighted Mean: SD & $\mathbf{3 . 9 1 : 1 . 1 5 6}$ \\
\hline Verbal Interpretation & \multicolumn{3}{|l}{} \\
\hline
\end{tabular}

Legend

4.20-5.00

$3.40-4.19$

2.60-3.39

1.80-2.59

1.00-1.79

\section{Remarks}

Very Much

Quite a bit

Somewhat

Very Little

Not Really
Verbal Interpretation

Always

Often

Sometimes

Seldom

Never

It reveals also in the table that the role of the teachers in guiding the online learners in taking responsibility on their daily activities has $(\mathrm{M}=4.31, \mathrm{SD}=0.95)$ and a verbal interpretation of Always. This means that this role is very much perceived by the students during their online classes and the role is always performed by the teachers.

Furthermore, the table shows also that the role on coordinating with the parents regarding the academic status of the students got the lowest $(\mathrm{M}=3.37, \mathrm{SD}=1.44)$ and a verbal interpretation of Sometimes. This means that the role is somewhat perceived by the learners and performed by their online teachers sometimes during English online distance learning classes.. 


\section{SJIF Impact Factor 2021: 8.013| ISI I.F.Value:1.241| Journal DOI: 10.36713/epra2016 ISSN: 2455-7838(Online) EPRA International Journal of Research and Development (IJRD) Volume: 6 | Issue: 7 | July 2021 \\ - Peer Reviewed Journal}

The overall mean of 3.91 with a supported standard deviation of 1.156, it indicated that the teachers' affective roles in English online distance learning are quite a bit perceived by the learners and the roles are often performed by the teachers during the first and second grading periods.

Table 2 presents the level of teachers' planner roles as e-classroom designer. The result shows that the roles of the teachers in picking the right tools $(\mathrm{M}=4.49, \mathrm{SD}=0.84)$, sending invites and clear instructions $(\mathrm{M}=4.55, \mathrm{SD}$ $=0.86$ ), securing synchronous passwords $(\mathrm{M}=4.51, \mathrm{SD}=0.90)$, setting ground rules $(\mathrm{M}=4.55, \mathrm{SD}=0.81)$, showing a face during synchronous classes $(\mathrm{M}=4.73, \mathrm{SD}=0.55)$, asking challenging questions to ensure students understand the lessons $(\mathrm{M}=4.58, \mathrm{SD}=0.68)$, monitoring the chat of the students $(\mathrm{M}=4.51, \mathrm{SD}=0.80)$, and giving assignments that enable students to communicate with their classmates $(\mathrm{M}=4.27, \mathrm{SD}=0.79)$ are all verbally interpreted as Always. This means that the mentioned roles are always performed by the teachers as the students very much perceived them during the English online distance learning classes in the first and second grading periods.

Table 2. Level of the Teachers' Planner Roles as e-Classroom Designer

\begin{tabular}{|c|c|c|c|c|}
\hline \multicolumn{2}{|l|}{ Statements } & Mean & SD & V.I. \\
\hline \multicolumn{2}{|c|}{ Pick the right tool: The teacher uses the right tools in designing the online classroom } & 4.49 & 0.84 & Always \\
\hline \multicolumn{2}{|c|}{$\begin{array}{l}\text { Send invites and clear instructions: The teacher sends invites for every synchronous class and } \\
\text { gives clear instructions in every activity in the online classroom }\end{array}$} & 4.55 & 0.86 & Always \\
\hline \multicolumn{2}{|c|}{$\begin{array}{l}\text { Stay Secure: The teacher does not share synchronous meeting passwords in public; he/she knows } \\
\text { how to manage the participants (like muting and muting); he/she knows all the students inside the } \\
\text { classroom. }\end{array}$} & 4.51 & 0.90 & Always \\
\hline \multicolumn{2}{|c|}{$\begin{array}{l}\text { Set ground rules: The teacher sets rules and expectations for the students to take the activities } \\
\text { seriously and to provide a safe learning environment and equal opportunities for all to participate. }\end{array}$} & 4.55 & 0.81 & Always \\
\hline \multicolumn{2}{|c|}{$\begin{array}{l}\text { Recording of discussions or lessons: The teacher records your synchronous classes for the } \\
\text { students who cannot attend the synchronous class. }\end{array}$} & 3.54 & 1.54 & Often \\
\hline \multicolumn{2}{|c|}{$\begin{array}{l}\text { Show your face: The teacher shows her/his face during synchronous class discussions to } \\
\text { maintain the students' attention and stimulate a more personal connection with the learners. }\end{array}$} & 4.73 & 0.55 & Always \\
\hline \multicolumn{2}{|c|}{$\begin{array}{l}\text { Check-in periodically: The teacher asks challenging questions to ensure that the students } \\
\text { understand what has been discussed. The teacher treats everyone equally and entertains all } \\
\text { questions before moving to the next lesson. }\end{array}$} & 4.58 & 0.68 & Always \\
\hline \multicolumn{2}{|c|}{$\begin{array}{l}\text { Monitor the chat: The teacher asks the students to use the chat area to communicate. The teacher } \\
\text { advises the students to use proper spelling, grammar, and punctuations. Inflammatory or } \\
\text { disrespect is not tolerated in the chat area. }\end{array}$} & 4.51 & 0.80 & Always \\
\hline \multicolumn{2}{|c|}{$\begin{array}{l}\text { Provide interactive activities: The activities in the online classroom are interactive. There are } \\
\text { icebreaker activities, puzzles, presentations, pitches, peer reviews, quizzes, brainstorm sessions, } \\
\text { games and synchronous activities. }\end{array}$} & 4.02 & 0.96 & Often \\
\hline \multirow{2}{*}{\multicolumn{2}{|c|}{$\begin{array}{l}\text { Assignments: The teacher gives assignments that enable the students to talk or communicate with } \\
\text { their classmates. She/he gives time to explore other tools in the online classroom to familiarize } \\
\text { with the different learning materials, and she/he seeks feedbacks after class discussions. } \\
\text { Weighted Mean: SD }\end{array}$}} & 4.27 & 0.79 & Always \\
\hline & & \multicolumn{3}{|c|}{ 4.37: 0.961} \\
\hline \multicolumn{2}{|c|}{ Verbal Interpretation } & \multicolumn{3}{|c|}{ Always } \\
\hline Legend & Verbal Inte & \multicolumn{3}{|c|}{ Verbal Interpretation } \\
\hline $4.20-5.00$ & Very Much & \multicolumn{3}{|c|}{ Always } \\
\hline $3.40-4.19$ & Quite a bit & \multicolumn{3}{|c|}{ Often } \\
\hline $2.60-3.39$ & Somewhat & \multicolumn{3}{|c|}{ Sometimes } \\
\hline $1.80-2.59$ & Very Little & \multicolumn{3}{|c|}{ Seldom } \\
\hline $1.00-1.79$ & Not Really & \multicolumn{3}{|c|}{ Never } \\
\hline
\end{tabular}




\section{SJIF Impact Factor 2021: 8.013| ISI I.F.Value:1.241| Journal DOI: 10.36713/epra2016 ISSN: 2455-7838(Online) EPRA International Journal of Research and Development (IJRD)

Table 2 also shows that the roles of the teachers in recording the discussions $(\mathrm{M}=3.54, \mathrm{SD}=1.54)$ and providing interactive activities have the verbal interpretation of Often. This means that these roles are often performed by the teachers as quite a bit perceived by the learners during the English online distance learning classes.

The teachers were able to design and create online classrooms with a verbal interpretation of always, as indicated by the overall mean of 4.37 with a supported standard deviation of 0.961 . This means that the learners observed the roles are always performed by the teachers during their English online distance learning classes as they perceived the roles of the teachers very much.

The table 3 presents the level of the teachers' managerial roles as authority in teaching strategies. The result shows that the roles of the teachers in preparing and delivering lessons to improve students' reading, writing, and communication skills $(\mathrm{M}=4.63, \mathrm{SD}=0.62)$, assigning a reading list $(\mathrm{M}=4.32, \mathrm{SD}=0.87)$, teaching language skills across the curriculum $(\mathrm{M}=4.36, \mathrm{SD}=0.81)$, providing activities involving writing, speaking, drawing, watching, and listening to give students different opportunities to deepen their understanding of the lesson $(M=4.53, S D=0.67)$, providing activities that encourage cooperative learning to verbally express students' ideas to develop selfconfidence, as well as communication and critical thinking skills $(\mathrm{M}=4.34, \mathrm{SD}=0.79)$, and providing activities that appreciate the different genre of literature $(\mathrm{M}=4.48, \mathrm{SD}=0.74)$ are all verbally interpreted to Always. This means that the mentioned roles of the teachers as e-learning classroom designers are very much perceived by the learners as the roles are always performed by the teachers.

Table 3. Level of the Teachers' Managerial Roles as Authority in Teaching Strategies

\begin{tabular}{|l|l|l|l|}
\hline Statements & Mean & SD & V.I. \\
\hline $\begin{array}{l}\text { The teacher prepares and delivers lessons to improve students' reading, writing, and } \\
\text { communication skills. }\end{array}$ & 4.63 & 0.62 & Always \\
\hline The teacher assigns a reading list. The reading list contains material that is accessible online. & 4.32 & 0.87 & Always \\
\hline $\begin{array}{l}\text { The teacher teaches language skills across the curriculum. The teacher uses other subjects as } \\
\text { learning materials (like science articles, history articles, etc.) to teach English skills. }\end{array}$ & 4.36 & 0.81 & Always \\
\hline $\begin{array}{l}\text { The teacher encourages students to engage with Classic English cinema. The teacher recommends } \\
\text { appropriate films for the students to watch to improve the students' English skills and to help } \\
\text { students release stress during these trying times. }\end{array}$ & 3.97 & 1.06 & Often \\
\hline $\begin{array}{l}\text { The teacher uses newspaper published online to build brilliant vocabulary and familiarize the } \\
\text { students with excellent sentence structures to improve English reading and writing skills. }\end{array}$ & 3.68 & 1.11 & Often \\
\hline $\begin{array}{l}\text { The teacher provides activities involving writing, speaking, drawing, watching, and listening to } \\
\text { give students different opportunities to deepen their understanding of the lesson. }\end{array}$ & 4.53 & 0.67 & Always \\
\hline $\begin{array}{l}\text { The teacher incorporates students' native languages. The teacher allows students to speak in their } \\
\text { native language then helps them to translate in English to fully understand the lessons. }\end{array}$ & 3.91 & 1.23 & Often \\
\hline $\begin{array}{l}\text { The teacher provides local reading materials to easily understand the context of the text. } \\
\text { (Example: The history of Paru-paro festival in Dasmarinas) }\end{array}$ & 3.97 & 1.08 & Often \\
\hline $\begin{array}{l}\text { The teacher provides activities that encourage cooperative learning to verbally express students' } \\
\text { ideas to develop self-confidence, as well as communication and critical thinking skills. }\end{array}$ & 4.34 & 0.79 & Always \\
\hline $\begin{array}{l}\text { The teacher provides activities that appreciate the different genre of literature (like poetry, prose, } \\
\text { fiction, nonfiction, short story, nevels, etc.). }\end{array}$ & 4.48 & 0.74 & Always \\
\hline Weighted Mean: SD & $\mathbf{4 . 2 2 : ~} \mathbf{0 . 9 6 2}$ \\
\hline Verbal Interpretation & Always & \\
\hline
\end{tabular}

Legend

4.20-5.00

$3.40-4.19$

2.60-3.39

$1.80-2.59$

$1.00-1.79$

\section{Remarks}

Very Much

Quite a bit

Somewhat

Very Little

Not Really
Verbal Interpretation

Always

Often

Sometimes

Seldom

Never 


\section{SJIF Impact Factor 2021: 8.013| ISI I.F.Value:1.241| Journal DOI: 10.36713/epra2016 ISSN: 2455-7838(Online) EPRA International Journal of Research and Development (IJRD) \\ Volume: 6 | Issue: 7 | July 2021 \\ - Peer Reviewed Journal}

The table also shows that the roles of the teachers in encouraging the students to engage with Classic English cinema $(\mathrm{M}=3.97, \mathrm{SD}=1.06)$, using newspaper published online to build brilliant vocabulary and familiarizing the students with excellent sentence structures to improve English reading and writing skills $(\mathrm{M}=3.68, \mathrm{SD}=1.11)$, allowing the students to speak in their native language then help them to translate in English to fully understand the lessons $(\mathrm{M}=3.91, \mathrm{SD}=1.23)$, and providing local reading materials to easily understand the context of the text $(\mathrm{M}=$ $3.97, \mathrm{SD}=1.08$ ) are all verbally interpreted to Often. This means that these behaviors are perceived quite a bit by the student as the teachers often performed the roles during the English online distance learning classes.

The overall mean of 4.22 with a supported standard deviation of 0.962 , this indicated that the teachers' managerial roles in English online distance learning as authority in teaching strategies in English class has a verbal interpretation of Always. This means that the learners observed the managerial roles are always performed by the English online distance learning teachers as very much perceived by the students.

Table 4 presents the level of the students' behavior in English online distance learning when reading. The results shows that the students remember information from their reading class when they print the reading materials $(\mathrm{M}=3.54, \mathrm{SD}=0.81)$, it is more convenient to read their assigned readings electronically/digitally $(\mathrm{M}=3.78, \mathrm{SD}=$ $0.98)$, they highlight and notate printed course readings $(\mathrm{M}=3.80, \mathrm{SD}=1.11)$, scan and skim a reading material based on the information needed in their activity $(\mathrm{M}=3.76, \mathrm{SD}=0.95)$, and make a summary of the reading materials after they read them $(\mathrm{M}=3.54, \mathrm{SD}=1.11)$ are all verbally interpreted to Often. This means that these situational behaviors are all often performed by the learners during their English online distance learning classes.

Table 4. Level of Students' Behavior in English Online Distance Learning when Reading

\begin{tabular}{|c|c|c|c|}
\hline Statements & Mean & SD & V.I. \\
\hline I remember information from my reading class when I print them & 3.54 & 0.81 & Often \\
\hline It is more convenient to read my assigned readings electronically/digitally & 3.78 & 0.98 & Often \\
\hline I usually highlight and notate my printed course readings & 3.80 & 1.11 & Often \\
\hline I usually highlight and annotate my electronic readings & 3.39 & 1.21 & Sometimes \\
\hline I read when it is required in the activity & 4.43 & 0.83 & Always \\
\hline I read every day my teacher does not require even it & 3.23 & 1.02 & Sometimes \\
\hline I only scan and skim a reading material based on the information needed in my activity & 3.76 & 0.95 & Often \\
\hline $\begin{array}{l}\text { I do not read the given reading material; instead, I search on the internet for the } \\
\text { information needed in the activity }\end{array}$ & 2.64 & 1.07 & Sometimes \\
\hline I make a summary of the reading materials after I read them & 3.54 & 1.11 & Often \\
\hline $\begin{array}{l}\text { I use dictionary if I do not understand a word, or I use the internet to get more } \\
\text { information about the reading materials. }\end{array}$ & 4.34 & 0.97 & Always \\
\hline Weighted Mean: SD & \multicolumn{3}{|c|}{ 3.64: 1.122} \\
\hline Verbal Interpretation & \multicolumn{3}{|l|}{ Often } \\
\hline Remarks & \multicolumn{3}{|c|}{ Verbal Interpretation } \\
\hline Very Much & \multicolumn{3}{|c|}{ Always } \\
\hline Quite a bit & \multicolumn{3}{|c|}{ Often } \\
\hline Somewhat & \multicolumn{3}{|c|}{ Sometimes } \\
\hline Very Little & \multicolumn{3}{|c|}{ Seldom } \\
\hline Not Really & \multicolumn{3}{|c|}{ Never } \\
\hline
\end{tabular}

The table further discusses that the students read when it is required in the activity $(\mathrm{M}=4.43, \mathrm{SD}=0.83)$ and they use dictionary if they do not understand a word, or they use the internet to get more information about the reading materials $(\mathrm{M}=4.34, \mathrm{SD}=0.97)$ are verbally interpreted as Always. This means that the learners always do the mentioned behaviors in their English online distance learning classes as they very much perceived the given situational behaviors while the behavior regarding on highlighting and annotating electronic readings $(M=3.39, D=$ 


\section{SJIF Impact Factor 2021: 8.013| ISI I.F.Value:1.241| Journal DOI: 10.36713/epra2016 ISSN: 2455-7838(Online) EPRA International Journal of Research and Development (IJRD) Volume: 6 | Issue: 7 | July 2021 \\ - Peer Reviewed Journal}

1.21) and on the behavior of not reading the given reading material; instead, they search on the internet for the information needed in the activity $(\mathrm{M}=2.64, \mathrm{SD}: 1.07)$ are all verbally interpreted to Sometimes. This means that these behaviors are somewhat perceived by the learners, and they act these behaviors sometimes during their English online distance learning classes.

The overall mean of 3.64 with a supported standard deviation of 1.122 indicated that students' behavior in English online distance learning in reading with Often as verbal interpretation. This means that the students often do the given behavioral situations when they are reading materials as they perceived quite a bit the behavioral situations.

Table 5 presents the level of students' behavior in English online distance learning when writing. The result shows that the students search on the internet about the topic before they write $(\mathrm{M}=4.14, \mathrm{SD}=0.88)$, write articles when it is required in the activity in their online class $(\mathrm{M}=4.13, \mathrm{SD}=0.93)$, write literary pieces every day even it is not required by the teacher $(\mathrm{M}=2.56, \mathrm{SD}=1.02)$, only write based on the information needed in the activity $(\mathrm{M}=$ $4.04, \mathrm{SD}=0.78)$, ask the teacher a rubric as a guide when writing $(\mathrm{M}=3.40, \mathrm{SD}=1.15)$, and use outlining, editing, and revising when writing or composing an article $(\mathrm{M}=3.99, \mathrm{SD}=0.99)$ are all verbally interpreted to Often. This means that the mentioned behaviors of the students above are all perceived by students quite a bit and they are often performed by the learners during the English online distance learning classes.

Table 5. Level of Students' Behavior in English Online Distance Learning when Writing

\begin{tabular}{|l|l|l|c|}
\hline Statements & Mean & SD & V.I. \\
\hline I search on the internet about the topic before I write & 4.14 & 0.88 & Often \\
\hline I write articles when it is required in the activity in my online class & 4.13 & 0.93 & Often \\
\hline $\begin{array}{l}\text { I write every day even it is not required by my teacher like poems, stories, legends } \\
\text { etc. }\end{array}$ & 2.56 & 1.02 & Often \\
\hline I only write based on the information needed in my activity & 4.04 & 0.78 & Often \\
\hline I observe grammar rules when writing articles & 4.36 & 0.81 & Always \\
\hline I ask my teacher a rubric as my guide when writing & 3.40 & 1.15 & Often \\
\hline I use outlining, editing, and revising when writing an article & 3.99 & 0.99 & Often \\
\hline I used grammar apps online to check my grammar, spelling, and punctuations & 3.15 & 1.34 & Sometimes \\
\hline I ask my teacher to give a feedback on the article I have written & 2.69 & 1.27 & Sometimes \\
\hline I ask someone to read my article before I pass it in our online portals & 3.17 & 1.41 & Sometimes \\
\hline Weighted Mean: SD & $\mathbf{3 . 5 6 : 1 . 2 4 0}$ & \\
\hline Verbal Interpretation & Often & \\
\hline Legend & Verbal Interpretation \\
4.20-5.00 Remarks & Always & \\
$3.40-4.19$ & Often & \\
$2.60-3.39$ & Sometimes & \\
$1.80-2.59$ & Seldom & \\
$1.00-1.79$ & Never &
\end{tabular}

Table 5 also illustrates that the students use grammar apps online to check grammar, spelling, and punctuations $(\mathrm{M}=3.15, \mathrm{SD}=1.34)$, ask teachers to give a feedback on the article they have written $(\mathrm{M}=2.69, \mathrm{SD}=$ 1.27), and ask someone to read their article before they pass it on their online portals $(\mathrm{M}=3.17, \mathrm{SD}=1.41)$ are all verbally interpreted to Often. This means that the behaviors are perceived by the students quite bit and they do them often during the English online distance learning classes.

Moreover, the table also explains that the students always observe grammar rules when they are writing articles $(\mathrm{M}=4.36, \mathrm{SD}=0.81)$ with a verbal interpretation of Always. This means that the students are always aware on the grammar rules when they are writing during their English online distance learning classes. 


\section{SJIF Impact Factor 2021: 8.013| ISI I.F.Value:1.241| Journal DOI: 10.36713/epra2016 ISSN: 2455-7838(Online) EPRA International Journal of Research and Development (IJRD) Volume: 6 | Issue: 7 | July 2021 - Peer Reviewed Journal}

The level of students' behavior in English online distance learning in writing has an overall mean of 3.56 and a standard deviation of 1.240. This means that the given behaviors are often done by the students during their English online distance learning as they perceived them quite a bit.

Table 6 presents the level of students' behavior in English online distance learning when listening and viewing or watching. The result shows that the students pause a video or recorded material to note information exactly $(M=4.14, S D=1.00)$, listen or watch when the teacher requires it $(M=3.55, S D=1.26)$, prefer to watch or listen on the internet using cellular phone or laptop than on television or radio $(\mathrm{M}=3.83, \mathrm{SD}=0.94)$, only listen or watch based on the information needed in the activity $(\mathrm{M}=3.69, \mathrm{SD}=0.98)$, and replay videos or any recorded materials to confirm information $(\mathrm{M}=4.19, \mathrm{SD}=0.97)$ are all with a verbal interpretation of Often. This means that the learners often do these behaviors during the English online distance learning as they perceived quite a bit the stated behaviors.

Table 6. Level of students' behavior in English online distance learning when Listening and Viewing

\begin{tabular}{|l|l|l|c|}
\hline Statements & Mean & SD & V.I. \\
\hline I take down notes when listening and watching/viewing videos or recorded materials & 4.21 & 0.92 & Always \\
\hline I pause a video or recorded material to note information exactly & 4.14 & 1.00 & Often \\
\hline I only listen or watch when my teacher requires it & 3.55 & 1.26 & Often \\
\hline I listen or watch the news every day my teacher does not require even it & 3.28 & 1.31 & Sometimes \\
\hline $\begin{array}{l}\text { I prefer to watch or listen on the internet using my cellular phone or laptop than on television or } \\
\text { radio }\end{array}$ & 3.83 & 0.94 & Often \\
\hline I only listen or watch based on the information needed in my activity & 3.69 & 0.98 & Often \\
\hline I do not watch; instead, I search on the internet for the information needed in the activity & 3.14 & 1.01 & Sometimes \\
\hline I replay videos or any recorded materials to confirm information & 4.19 & 0.97 & Often \\
\hline I record audio notes using my own voice through my gadgets & 2.45 & 1.24 & Seldom \\
\hline I cut and save a part of the video or audio for my reference & 2.89 & 1.29 & Sometimes \\
\hline Weighted Mean: SD & $\mathbf{3 . 5 4 :} \mathbf{1 . 2 3 4}$ \\
\hline Verbal Interpretation & $\mathbf{O f t e n}$ & \\
\hline
\end{tabular}

Legend

4.20-5.00

3.40-4.19

2.60-3.39

1.80-2.59

1.00-1.79
Remarks

Very Much

Quite a bit

Somewhat

Very Little

Not Really
Verbal Interpretation

Always

Often

Sometimes

Seldom

Never

Table 6 further reveals that the learners listen or watch the news every day even the teacher does not require $(\mathrm{M}=3.28, \mathrm{SD}=1.31)$, they do not watch; instead, they search on the internet for the information needed in the activity $(\mathrm{M}=3.14, \mathrm{SD}=1.01)$, and cut and save a part of the video or audio for a reference $(\mathrm{M}=2.89, \mathrm{SD}=1.29)$ are all with a verbal interpretation of Sometimes. This means that the learners somewhat perceived the mentioned behaviors and do them sometimes during the English online distance learning classes.

Furthermore, the table also discloses that the students seldom record audio notes using their own voice through their gadgets $(\mathrm{M}=2.45, \mathrm{SD}=1.24)$ but they always take down notes when listening and watching/viewing videos or recorded materials $(\mathrm{M}=4.21, \mathrm{SD}=0.92)$ during the English online distance learning classes.

The level of students' behavior in English online distance learning has an overall mean of 3.54 with a supported standard deviation of 1.234. This means that the behavioral situations given in the table above are done often by the learners when viewing and listening. This implies that the given behavioral conditions in the table during the first and second grading periods of the school year 2020-2021 are quite a bit perceived by the learners during their English online distance learning classes. 


\section{SJIF Impact Factor 2021: 8.013| ISI I.F.Value:1.241| Journal DOI: 10.36713/epra2016 ISSN: 2455-7838(Online) EPRA International Journal of Research and Development (IJRD) Volume: 6 | Issue: 7 | July 2021

\author{
- Peer Reviewed Journal
}

The 7 presents the achievement of the students in English online distance learning during the first and second grading periods of the school year 2020-2021. The result shows that out of 95 students, the Second Grading received the highest ( $M=90.37, \mathrm{SD}=4.91)$ grades and verbally interpreted as Outstanding. At the same time, the First Grading received the lowest $(\mathrm{M}=89.35, \mathrm{SD}=4.46)$ grades and verbally interpreted as Very Satisfactory.

Table 7. Achievement of the Students in English Online Distance Learning during the First and Second Grading Periods

\begin{tabular}{|l|c|c|c|c|c|}
\hline Grading Period & Lowest Grade & Highest Grade & Mean & Standard Deviation & Verbal Interpretation \\
\hline First Grading & 75 & 96 & 89.35 & 4.46 & Very Satisfactory \\
\hline Second Grading & 75 & 99 & 90.37 & 4.91 & Outstanding \\
\hline Overall & $\mathbf{7 5}$ & $\mathbf{9 9}$ & $\mathbf{8 9 . 8 6}$ & $\mathbf{4 . 7 0 2}$ & Very Satisfactory \\
\hline
\end{tabular}

Legend:

Scale

$90 \%-100 \%$

$85 \%-89 \%$

$80 \%-84 \%$

$75 \%-79 \%$

Below $75 \%$
Verbal Interpretation
Outstanding
Very Satisfactory
Satisfactory
Fairly Satisfactory
Did not meet Expectation

With the overall mean of 89.86 and supported value of the standard deviation of 4.702 and the (Lowest Grade $=75$, Highest Grade $=99$ ), the students' achievement in English online distance learning during the first and second grading periods has a verbal interpretation of Very Satisfactory. This implied that the teachers' roles and students' behavior contributed very satisfactorily to the English online distance learners.

Table 8 presents the relationship of the teachers' roles and the students' behavior in English online distance learning during the first and second grading periods of the school year 2020-2021.

The Affective Roles, Planner Roles and Managerial Roles of Teachers in Reading, Writing and Listening and Viewing shows slight to moderate correlation but a substantial relationship and have an analysis of significance at 0.05 level. This means that the teachers' roles directly relate to the students' behavior in English online distance learning.

Table 8. Relationship of the teachers' roles and the students' behavior in English online distance learning

\begin{tabular}{|l|l|l|l|l|l|}
\hline Teachers' Roles & Students' Behavior & r - value & p-value & Degree of Correlation & Analysis \\
\hline \multirow{2}{*}{$\begin{array}{l}\text { Teachers' } \\
\text { Affective Roles }\end{array}$} & When reading & 0.4909 & 0.0000 & Moderate correlation & Significant \\
\cline { 2 - 6 } & When writing & 0.3403 & 0.0007 & Slight correlation & Significant \\
\cline { 2 - 6 } & When listening and viewing & 0.4057 & 0.0000 & Moderate correlation & Significant \\
\hline \multirow{2}{*}{$\begin{array}{l}\text { Teachers' Planner } \\
\text { Roles }\end{array}$} & When reading & 0.4638 & 0.0000 & Moderate correlation & Significant \\
\cline { 2 - 6 } & When writing & 0.2516 & 0.0139 & Slight correlation & Significant \\
\cline { 2 - 6 } & When listening and viewing & 0.2880 & 0.0046 & Slight correlation & Significant \\
\hline \multirow{2}{*}{$\begin{array}{l}\text { Teachers' } \\
\text { Managerial Roles }\end{array}$} & When reading & 0.5503 & 0.0000 & Moderate correlation & Significant \\
\cline { 2 - 6 } & When writing & 0.3422 & 0.0007 & Slight correlation & Significant \\
\cline { 2 - 6 } & When listening and viewing & 0.3899 & 0.0001 & Slight correlation & Significant \\
\hline
\end{tabular}

Legend

Scale Degree of Correlation

$\pm 0.00 \quad$ no correlation, no relationship

$\pm 0.01- \pm 0.20$ very low correlation, almost negligible relationship

$\pm 0.21- \pm 0.40$ slight correlation, definite but small relationship

$\pm 0.41- \pm 0.70$ moderate correlation, substantial relationship

$\pm 0.71- \pm 0.90$ high correlation, marked relationship

$\pm 0.91- \pm 0.99$ very high correlation, very dependable relationship

$\pm 1.00 \quad$ perfect correlation, perfect relationship

(c) 2021 EPRA IJRD | Journal DOI: https://doi.org/10.36713/epra2016 | www.eprajournals.com |97 | 


\section{SJIF Impact Factor 2021: 8.013| ISI I.F.Value:1.241| Journal DOI: 10.36713/epra2016 ISSN: 2455-7838(Online) EPRA International Journal of Research and Development (IJRD) Volume: 6 | Issue: 7 | July 2021 \\ - Peer Reviewed Journal}

Since a significant relationship is found in the affective roles of the teachers in the behavior of the students when they are reading, writing, listening and viewing, it is important to consider the given affective roles of the teachers to motivate the learners to share their feelings and help them to cope with the presents situation of the learners brought by the pandemic.

In addition, the behavior of the learners has direct relationship to the affective roles of the teachers, it is then significant to consider the given behavioral situations when teaching the online learners. In considering these behavioral situations, the teacher-student relationship will be developed, and the teaching-learning process will be successful.

The planner roles of the teachers have also found a significant relationship to the behavior of the students during online distance learning in English class. Since it is found the relation of the variables are significant, it is suggested that the given planner roles of the teachers are playing a good job in attending the educational needs of the students in learning English subject. It is substantial also to consider the given behavior of the students in planning lessons together with the activities and techniques to be used in online distance learning education.

Lastly, the table shows also that the students' behaviors have a significant relationship to the roles of the teachers as authority in teaching strategies. It is recommended that the given behavioral situations of the learners and the given roles of the teachers during online distance learning classes are to be considered when planning, creating, and handling English online distance learning.

As a whole, the data shows a relationship between the teachers' roles and the students' behavior in English online distance learning during the first and second grading periods at a 0.05 level of significance. It shows that the hypothesis stating that "There is no significant relationship of the teachers' roles and the students' behavior in English online distance learning during the first and second grading periods of the school year 2020-2021" is rejected, it can be inferred that there is "significant" relationship between them.

\section{CONCLUSION}

In view of the aforementioned findings, the study has drawn the following conclusions:

1. The students' behaviors depend on the teachers' roles during English online distance learning.

2. The teachers' roles and the students' behavior contribute to the students' level of performance in English online distance learning.

3. Among the three categories of the teachers' roles (affective roles, planner roles, managerial roles), the affective roles got the lowest student's perception.

4. The online distance teachers seldomly coordinate with the learners' parents regarding the students' academic status in this time of the pandemic.

5. Online distance learning teachers seldomly record and send the discussion to the students who were unable to attend the synchronous classes.

\section{ACKNOWLEDGEMENT}

The undertaking and completion of this study has been made possible because of the support and assistance of some people. The author hereby expresses his sincerest gratitude to the following who shared their authentic and unselfish concern, assistance, and spiritual support:

OUR HEAVENLY FATHER, the ultimate Creator of all things for His countless gifts of love, hope, knowledge, and strength to make this research fruitful.

LAGUNA STATE POLYTECHNIC UNIVERSITY, his Alma Mater, for serving as an instrument to achieve the researcher's goals and become professionally developed.

MARIO R. BRIONES, Ed.D., University President, for his great endeavor in helping individuals who yearn for professional growth in the different professions. 


\section{SJIF Impact Factor 2021: 8.013| ISI I.F.Value:1.241| Journal DOI: 10.36713/epra2016 ISSN: 2455-7838(Online) EPRA International Journal of Research and Development (IJRD) Volume: 6 | Issue: 7 | July 2021 \\ - Peer Reviewed Journal}

NIMFA G. DIMACULANGAN, Ph.D., his thesis adviser for her unending considerations, helping hands in the whole process of the study; for her incomparable support and brilliant ideas, her intellectual insights and considerable suggestions in bringing out the best of the study.

MERILYN P. JUACALLA, Ed.D., his Statistician, for undertaking the statistical tasks brilliantly and for her guidance and moral support in upbringing the study's credibility.

CAEZAR D. PAMIN, Ph.D., in his loving memory, the former adviser of the researcher, for his positive criticisms, comments and suggestions for the enhancement of the first parts of the study.

ALBINA BUNYI, Ed.D., Technical Expert, for her immense support and pedagogic pieces of advice in the duration of the study.

MARY GRACE A. ILAGAN, Ph.D., his external panel, for helping and guiding him in the details of the manuscript.

Mrs. REA C. BUNAN, Principal of Pag-asa National High School for her approval to conduct the study in her school and for her selflesssupport and assistance.

\section{REFERENCES}

1. Abu-Dabat, Z. Teacher's Roles in Counselling and Reforming the Academic Delay in Pupils of the Essential Stage in the Primary School. American International Journal of Social Science, 2013

2. Ahmed, A. Literature and Its Influence on Human Life. Rajkiya Engineering College, Chandpur, Bijor, 2017

3. Allan, W. Why literary genres matter. Oxford University Press's Academic Insights for the Thinking World/Blog, 2014

4. Ali, S. Impacts of Watching Videos on Academic Performance at University Level. European Journal of Education Studies, 2019

5. Anderson,S. Common Writing Challenges High-School Students Encounter and Ways to Help Them. Today Parenting Team, 2017

6. Bana, A. Students' Perception of Using the Internet to Develop Reading Habits: A Case Study at the English Education Department of Universitas Kristen Indonesia. Journal of English Teaching, 2020

7. Brink, S. The Importance of Writing Skills. Europena Commission. 2020

8. Brunk, A. Teacher Perceptions Regarding the Role of the School Counselor, 2011

9. Bulut, P. The Effect of Primary School Students' Writing Attitudes and Writing Self-Efficacy Beliefs on Their Summary Writing Achievement. International Electronic Journal of Elementary Education, 2017

10. Canpolat M. et.al. Active Listening Strategies of Academically Successful University Students. Eurasian Journal of Educational Research, 2015

11. Cordeur, M. Teaching reading across the curriculum in secondary school. Stellenbosch University, 2012

12. Durairaj, K. Analysis of students' listening behavior patterns in an asynchronous discussion forum. Science Direct Procedia - Social and Behavioral Sciences, 2014

13. Dekin, S. Why Teenagers Need To Start Discussing Their Emotions. Mission Harbor Behavioral Heath, 2020

14. Elleman, A. et.al Reading Comprehension Research: Implications for Practice and Policy. Policy Insights from the Behavioral and Brain Sciences, 2019

15. Ellsworth, J. Teacher as Counselor. Center for Technology Enhanced Learning, 2001

16. Farrell, L. et.al. The Simple View of Reading. Reading Rockets, 2019

17. Ferlazzo, L. Twenty Tips for Online Instruction. Education week, 2020

18. Georgiana, D. Teacher`s Role as a Counsellor. Procedia - Social and Behavioral Sciences, 2015

19. Gerstein, J. The Role of the Educator as a Maker Educator. ASCD Books and Publications, 2019

20. Hale, L. Teacher Knowledge of School Counselor Responsibilities. The College at Brockport: State University of New York, 2012

21. Isman, A. et.al. Roles of the Students and Teachers in Distance Education. Turkish Online Journal of Distance Education, 2004

22. Kabooha, R. Using Movies in EFL Classrooms: A Study Conducted at the English Language Institute (ELI), King Abdul-Aziz University. Canadian Center of Science and Education, 2016

23. Kirangari, T. The Effectiveness of Guidance and Counseling in Managing Students' Discipline in Public Secondary Schools in Kandara District, Murang `a County, Kenya, 2010

24. Kramer, K. Using Self-help Bibliotherapy in Counselling, 2006 
25. Kuama, S. et.al. Is Online Learning Suitable for All English Language Students?. Prince of Songkla University (PASAA), 2016

26. Mageto, J.The Purpose of reading literature. GRIN Publishing, 2017

27. MegawatI, W. et.al. The Impact of Teachers' Verbal and Non-Verbal Communication on Students' Motivation in Learning English. UNNES Journal English Education Journal, 2020

28. Naibaho, L. Teachers' Roles on English Language Teaching: A Students Centered Learning Approach. International Journal of Research, 2019

29. Pappas, C. 8 Creative Ideas for Active Learning Activities to Include in Your eLearning Course. E-Learning Industry (eBook). 2017

30. Peratt, C. 5 Ground Rules for Online Classroom Discussion. Corolado State University Online, 2020

Pfost, M. et.al. Students' Extracurricular Reading Behavior and the Development of Vocabulary and Reading Comprehension. Science Direct, 2013

31. Pourhosein Gilakjani, A. The Significance of Listening Comprehension in English Language Teaching. Islamic Azad University of Lahijan, 2016

32. Poth, R. Choosing the Right Tools for Remote Learning. Getting smart, 2020

33. Rae, J. The Importance of Writing Skills: Why It Matters to the Student. Easy Reader and Peninsula, 2020

34. Sadiku, L. The Importance of Four Skills Reading, Speaking, Writing, Listening in a Lesson Hour. European Journal of Language and Literature Studies, 2015

35. Sharma, S. Six Reasons Why You Should Always Record Online Classes. Wiz IQ Blog, 2020

36. Spencer, J. The Power of Student Check-Ins During Distant Learning and Hybrid Courses, 2020

37. Schukei, A. How to Keep Students Safe When Learning Online. The Art of Education University, Web. 2005

38. Swai, E. Role of Instructional Materials in Academic Performance in Community Secondary Schools in Rombo District, 2016

39. Tafida, A. Using Newspapers in Teaching English as a Second Language. Scienceweb Publishing, 2014

40. Taylor-Massey, J. Redefining Teaching: The Five Roles of the Online Instructor. Colorado State University Online Blog, 2015

41. Törnqvist, A. Oral Communication in the English Language Classroom. University of Kalmar, School of Human Sciences, 2008

42. Tsan-Jui Cheng, R. Reading Online in Foreign Languages: A Study of Strategy Use. International Review of Research in Open and Distributed Learning, 2016

43. White, B. Free eBook: Six Positive Messages to Guide a Year of Teaching and Learning, 2020

44. Willson, J. Why Writing Skills are Important, 2020

45. Wright, D. Why Read Literature?. Memoria Press. 2019

46. Zhang, X. An Analysis of Online Students' Behaviors on Course Sites and the Effect on Learning Performance: A Case Study of Four LIS Online Classes. Journal of Education for Library and Information Science, 2016

47. http://www.water-msc.org/en/knowledge_base/role_of_instructor2.pdf

48. https://www.researchgate.net/publication/26458006_Roles_of_the_Students_and_Teachers_in_Distance_Education

49. https://nces.ed.gov/surveys/frss/publications/2003015/pdf/questionnaire.pdf

50. https://www.researchgate.net/publication/222258718_A_theory_of_online_learning_as_online_participation/link/5c5d de86a6fdccb608b0fdc8/download

51. http://www.ascd.org/publications/books/119025/chapters/The-Role-of-the-Educator-as-a-Maker-Educator.aspx

52. https://online.purdue.edu/blog/education/what-do-instructional-designers-do

53. https://blog.hotmart.com/en/role-of-an-online-teacher/

54. https://blog.online.colostate.edu/blog/online-teaching/redefining-teaching-the-five-roles-of-the-online-instructor/

55. https://www.gettingsmart.com/2020/03/choosing-the-right-tools-for-remote-learning/

56. https://www.edweek.org/teaching-learning/opinion-twenty-tips-for-online-instruction/2020/08

57. https://theartofeducation.edu/2020/05/06/how-to-keep-students-safe-when-learning-online/

58. https://blog.online.colostate.edu/blog/education/5-discussion-ground-rules-for-the-online-classroom/

59. https://blog.wiziq.com/record-online-classes/

60. https://spencerauthor.com/student-check-ins/

61. https://elearningindustry.com/creative-ideas-active-learning-activities-include-elearning-course

62. https://publicpolicy.unc.edu/wp-content/uploads/sites/107/2015/07/The-Impact-of-Teacher-Preparation-on-StudentLearning-in-NC-Public-Schools-Jan-2010.pdf

63. https://keylinks.org/community/etextbooks-and-their-influence-on-the-student-learning-experience/

64. https://core.ac.uk/download/pdf/188220312.pdf

65. http://www.sciencewebpublishing.net/jerr/archive/2014/August/pdf/Tafida\%20and\%20Dalhatu.pdf

66. https://www.multibriefs.com/briefs/exclusive/help_or_hindrance.html\#.YIQ8PugzbIU

67. http://journal.unnes.ac.id/sju/index.php/eej 
SJIF Impact Factor 2021: 8.013| ISI I.F.Value:1.241| Journal DOI: 10.36713/epra2016

ISSN: 2455-7838(Online)

EPRA International Journal of Research and Development (IJRD)

Volume: 6 | Issue: 7 | July 2021

- Peer Reviewed Journal

68. https://blog.oup.com/2014/05/why-literary-genres-matter/

69. http://journals.euser.org/files/articles/ejls_jan_apr_15/Lorena_Manaj.pdf

70. https://www.diva-portal.org/smash/get/diva2:132912/FULLTEXT01.pdf

71. https://www.aliensandalibis.com/benefits-of-reading-books-of-different-genres/

72. https://www.memoriapress.com/articles/why-read-literature/

73. https://www.verywellfamily.com/developmental-benefits-of-reading-literature-3287753

74. https://epale.ec.europa.eu/en/blog/importance-writing-skills

75. https://easyreadernews.com/the-importance-of-writing-skills-why-it-matters-to-the-student/

76. https://missjessicaalbay.medium.com/why-writing-skills-are-important-3780b8d77419

77. https://journals.sagepub.com/doi/pdf/10.1177/2372732218816339

78. https://www.readingrockets.org/article/simple-view-reading

79. https://www.sciencedirect.com/science/article/abs/pii/S1041608013000642

80. http://creativecommons.org/licenses/by-nc-nd/4.0/

81. https://files.eric.ed.gov/fulltext/EJ1165376.pdf

82. https://files.eric.ed.gov/fulltext/EJ1134684.pdf

83. https://www.granthaalayahpublication.org/journals/index.php/granthaalayah/article/view/IJRG19_A04_2218

84. http://data.conferenceworld.in/NCCW/P129-134.pdf

85. https://www.researchgate.net/publication/306311479_The_Significance_of_Listening_Comprehension_in_English_La nguage_Teaching/link/59443cc845851525f890ad84/download

86. https://www.researchgate.net/publication/320951972_The_importance_of_listening_in_communication/link/5aOalbd7 a6fdcc2736dea3ba/download

87. https://files.eric.ed.gov/fulltext/EJ1117443.pdf

88. http://www.irrodl.org/index.php/irrodl/article/view/2567/3958

89. https://files.eric.ed.gov/fulltext/EJ1095569.pdf

90. https://filmthreat.com/features/how-movies-can-affect-your-health/

91. researchGatehttps://www.researchgate.net

92. https://sbtreatment.com/blog/teenagers-discussing-emotions/

93. https://files.eric.ed.gov/fulltext/EJ1266040.pdf

94. https://community.today.com/parentingteam/post/common-writing-challenges-high-school-students-encounter-andways-to-help-them

95. https://www.researchgate.net/publication/333809236_IMPACTS_OF_WATCHING_VIDEOS_ON_ACADEMIC_PERF ORMANCE_AT_UNIVERSITY_LEVEL

96. https://www.free-ebooks.net/register/12825209/b92f3e122f/membership

97. https://www.scribbr.com/methodology/correlational-research/ 